\title{
Democracy and Militarisation: War and Development
}

\section{Peter Marchetti and Cesar Jerez}

The Nicaraguan revolution captured world attention as the Sandinista guerrillas developed a political strategy which incorporated the business classes into the struggle against Somoza and promised a revolution based on the principles of political pluralism, a mixed economy, and international nonalignment. Although the political strategy of the Sandinistas for the overthrow of the dictatorship did not differ drastically from that of Cuban revolutionaries [see Harnecker 1987], they have been able, even under the blast of a US backed war, to maintain the general outlines of the model promised to the world during their struggle against Somoza. The image of a non-aligned, socialist, market society with victorious left-wing guerrillas and an electoral democracy is of such appeal that perhaps no war in modern history has had so many tourists visiting combat areas to see for themselves what was going on. One US based Christian organisation, Witness for Peace, has sent thousands of US citizens into the war zones of Nicaragua so that they act as a human shield between Nicaraguans and the US-backed Contras and provide US solidarity organisations with a steady flow of information regarding attacks against cilvilians.

From 1979 to 1981 , international solidarity movements projected what was, perhaps, too positive an image of the new Nicaragua. From 1981 onward, these utopian images and international support for the Sandinista revolution have been confronted by a series of counter-images generated by the Reagan administration and disenchanted liberals, who delight in being disappointed with alternative models such as that posed by the Sandinista revolution, thus permitting themselves to live more resignedly with the conservative restoration movements of Reagan and Thatcher.

The image of 'a Marxist dictatorship and Soviet foothold on continental North America', although not taken seriously by political analysts and scholars, has nonetheless played a crucial role in the war being waged by the United States against Nicaragua.

A less extreme but still distorted image of Nicaragua circulating quite broadly among scholars, especially in Europe and the United States, is that of 'militarisation of the revolution' or that 'the Sandinistas have fallen into the trap of militarisation set for them by the Reagan administration'. It is this image of militari- sation that I wish to contest. The first image has been amply discussed - if not debated - into the ground. A more thorough consideration of the second image may shed new light on the rigidly ideological outlines of debate generated around the first image.

The questions raised by the notion of militarisation that this article will take up are: have the chances for development in Nicaragua been buried by US military policy? Has the revolution become militarised? Has it lost touch with the people? Is it still capable of promoting the original development model that has inspired solidarity from so many different nations and social movements?

The first part of our argument deals with the definitions of development, and briefly characterises the type of war threatening development in Nicaragua. The second depicts a series of checks and balances against the appearance in Nicaragua of classical forms of societal militarisation.

\section{Imperialist Aggression, the State of the Art}

The term, low intensity war has often been criticised as an ambiguous euphemism for the contemporary form of imperialist military aggression. As President Daniel Ortega pointed out, "If the United States, with its population of 240 million, were subjected, as we have been for seven years, to a 'low intensity' war like this, the equivalent number of US victims would be 3 million. And the equivalent to the 22,000 Nicaraguans who have died would be 1,536,000 US dead'. In the words of Defence Minister, Humberto Oretga, 'Low intensity war is a figure of speech, an euphemism that attempts to cover up the costs of an extremely high level of military intervention and the preparation for a direct invasion'.

From our perspective, however, the term does describe one essential element of the situation affecting Nicaragua. The character of the war is lowintensity for the people of the United States, since proxy military forces fight their government's undeclared war for them. After the war in Vietnam,

\footnotetext{
${ }^{1}$ Statement by President Ortega. International Book Fair, 24 July, 1987. See Update, 'A Balance Sheet of Contra Aid: Human and Economic Costs of the Contra War, 1980-87', vol 6 no 32, 26 October, 1987 and Statement of Defence Minister Ortega, Barricada, 16 July, 1987.
} 
US military strategists developed a form of aggression that would leave them unhindered by public protest and relatively uncontrolled by democratic mechanisms established within the US State. The key to their autonomy, considered so essential after Vietnam, was lowering the human costs for the US populace. Low intensity war is undeclared war with undeclared costs. It must be remembered that what the Reagan administration has obtained from Congress is only a small percentage of the real flow of funds and materials to the counter-revolutionary forces through the programme of military manoeuvres in Honduras. ${ }^{2}$ The essential feature of the low-intensity war is that the military establishment promoting the aggression never becomes the object of public attack. In this sense, even the Iran Contra scandal, which placed before the US public some of the covert political and economic manoeuvring of the Reagan administration against Nicaragua and resulted in the press and politicians targeting the President's closest advisers, has never called into question the on-going activities of the US armed forces in Honduras, El Salvador and Panama. Military manoeuvres on a scale unheard of in the hemisphere go on in Honduras, coordinated from the South Command in Panama without the slightest note of protest from elected officials who supposedly oppose the administration's policy in the region. The cost of the manoeuvres, development of infrastructure and direct support for the Fuerzas Democraticas Nacionales (FDN) counter-revolutionaries has been estimated at over $\$ 6$ bn since 1981. Debates in Congress, and even the Iran Contra scandal, function within this type of warfare as smokescreens protecting the Pentagon. The Iran Contra scandal did undo the parallel government that the administration had created in order to carry out the low intensity, total war. That parallel government, in fact, served the purpose of keeping both the Pentagon and USAID distant from the 'dirtier' parts of the war, protecting them from public criticism, and permitting the real business of aggression via low-intensity, total war to go forward.

Because the key element of the strategy is protecting the US armed forces from the type of criticism that handcuffed US military might in the struggle against Vietnam, the non-military tactics of war take on added importance. The type of imperialist aggression of the early twentieth century encapsulated by Roosevelt's adage, 'Walk Softly and Carry a Big Stick', has been readapted by the Reagan administration to read 'Stomp Around Loudly, But Keep the Stick Well Hidden'. ${ }^{2}$

\footnotetext{
${ }^{2}$ An estimated $\$ 6$ bn has been spent on military manoeuvres, the military infrastructure necessary for a direct US invasion, and direct aid to the Contras. The latter is estimated at between $\$ 450 \mathrm{mn}$ and $\$ 500 \mathrm{mn}$ a year. For an in depth analysis of the low intensity war see Barry et al., 1987.
}

The low-intensity war against Nicaragua is total on the ground in Nicaragua. It is a multiple attack on all imaginable fronts. First, there is the guerrilla war being waged in the rural sector, whose principal objective has been to undermine the country's agrarian economy and drive a wedge between the revolutionary government and the peasantry, the largest single force in Nicaragua. ${ }^{3}$

Second, there has been the constant attempt to exacerbate tensions on the Atlantic Coast between the new government and the Miskito Indians and Creoles with the goal of dividing the country into an 'East and West Nicaragua'. This facet of the total war increased enormously the costs of national efforts to bring development and social programmes to this vast underdeveloped area. ${ }^{4}$

Third, there has been a constant effort to build an internal front within the cities of the Pacific coastal plain. In this aspect of the war, the US embassy played a key role in promoting the boycotting of elections, political dialogue, and the development of the Constitution by the political organisations representing elite business interests. The virulently anti-government newspaper, La Prensa, which had received funding from the US National Endowment for Democracy, played a crucial role in an on-going campaign to get these sectors of Nicaraguan society to forego the possibility of democratic opposition to the new government and gradually to switch their allegiances to the US funded FDN guerillas - or the Contras. Observers in Managua believe that if the parties of the Coordinadora Democratica had remained in the elections, the opposition to the Sandinistas would have won at least 45 per cent of the vote, enough to have given the former power of veto in the formulation of the Constitution. Instead, while the US funded a massive campaign of terror in rural areas, repeated rumours of plans to assassinate FSLN leaders became another type of distraction from development efforts, obliging the government to build up its secret services within the urban areas. ${ }^{5}$

Fourth, the subtle manipulation of the conservative reaction of the leadership of the Roman Catholic Church to the revolution, and the massive support for evangelical sects with ties to ultra-conservatives in the US have been directed towards the goal of isolating the

\footnotetext{
${ }^{3}$ For a detailed analysis of the strategy of the FDN among the peasantry and the response of the Nicaraguan government see, 'The Contras - Chronicle of a Defeat Foretold', Envio vol 6, no 67, February 1987.

${ }^{4}$ For background on the Atlantic Coast, see the special issue dedicated to the topic by Encuentro, nos 24-25, April-September, 1985. See also a summary of the 8 years of revolution on the Atlantic, 'Autonomia en la Costa Atlantica: Una Luz al Final del Tunel', Eucuentro, no 31, May-August, 1987.

'For an analysis of the electoral process sec 'La Administracion Reagan y el Pluralismo Politico en la Revolucion: Las Elecciones en la Neuva Nicaragua', Encuentro, no 31, May-August, 1987.
} 
Sandinistas from the dominant religious culture of the Nicaraguan masses. This ideological conflict has been one of the most wearing facets of the total war. ${ }^{6}$

The strategy of the low-intensity total war thus attempts to undermine the support of the peasantry, the indigenous and ethnic groups, the urban populace, the business classes, and the religious establishments for the FSLN. It does so by manipulating the military, economic, diplomatic, and ideological facets of the war so that each mutually reinforces the other.

\section{A Multi-faceted Attack}

Militarily, the strategy involves the use of proxy guerrilla forces while simultaneously sending signals to Nicaraguan military intelligence that a direct military invasion is just around the corner. The constant build-up of US forces and installations in Honduras has been the key to these psychological tactics which has forced Nicaragua to develop, finance, and maintain two different military establishments: (a) a standing army to defend against possible US invasion on its Pacific coast and urban areas and (b) a counter-insurgency guerrilla-style army to control the Contra units.

The vast majority of Nicaragua's military forces are dedicated to the first task. Were it not for the need to dissuade the Pentagon from unleashing a direct US invasion against Nicaragua, the country would need an army only half the size of those of Guatemala and El Salvador to control the Contras. Moreover, the military guarding the cities and the coasts represents a much heavier burden to the economy than the guerrilla-style forces fighting in the isolated mountain areas.

The defensive build-up against a possible US invasion was given priority by the Sandinistas from 1979 to late 1983. During that time the vast majority of resources went into building up an army that would make the Pentagon think before invading; the size and the quality of the army would preclude an 'easy-in, easyout' scenario such as that carried out by the US on the island of Grenada. During that same period, the Sandinistas paid less attention to the slow growth of the Contras. Local militia drawn from the peasantry as well as urban workers and cadres and serving for three to six month stints were the forces used to control the FDN. Later, with the growth of the FDN, Nicaragua was forced to draft and professionalise massive numbers of young men as members of the Batallones de Lucha Irregular (BLI), the counterinsurgency guerilla-style forces which have managed

\footnotetext{
${ }^{6}$ A good summary of the Church-State conflict can be found in ' $\mathrm{La}$ Iglesia Catolica en el Proceso Revolucionario', Encuentro, no 31 , May-August, 1987. For more detailed chronicles of Church-State relations in Nicaragua see Envio, vol 2 no 30, December 1983; vol 3 no 38, August 1984; vol 4 no 50, August 1985; vol 6, nos 77 and 78 , November and December 1987
}

to break the back of the counter-revolutionary threat. ${ }^{\text {? }}$

One of the basic purposes of this dual threat was to spread the Sandinistas thin and impose an unbearable economic cost on the national populace. By 1985, when the Sandinistas had developed both styles of defence, nearly 50 per cent of its national budget was dedicated to the war. The very location of the proxy war has affected Nicaragua's principal productive activities both in terms of labour, GDP, and foreign currency. Coffee, cattle, corn and beans are the backbone of Nicaragua's economy. All these activities are located principally in the war zone. The national herd is about half of what it was in 1977. Coffee production is down by about a third. There are shortages of beans since production was shifted to the Pacific coastal areas. Although corn production has been more than adequate and the prices are dropping in a period of hyper-inflation, Nicaragua has had to forego the use of land formerly dedicated to export crops in order to feed her people.

Turning back development and blaming increasing poverty on the Sandinista military regime has now become the principal goal of US aggression since the strategic setbacks suffered by the FDN during the 1985 and 1986 campaigns.

Economically, the direct costs of the war have totalled $\$ 1,228.7 \mathrm{mn}$ over the past eight years. As can be seen from Diagram 1, the major items in direct losses have been losses in production and blocked loans. Indirect and direct effects of the war on the GDP have totalled more than $\$ 3.6$ bn, nearly two full years of GDP since 1981 (see Table 1).

Diagram 2 shows the loss through destruction in capital goods and stock, while the data presented in Digrams 3 and 4 show the human losses in war and poverty what the Nicaraguan government refers to as the 'strategic defeat' of the counterrevolution. As can be seen in Diagram 2, the Contra war has produced more civilian than military dead (3218 as against 2496); hardly a statistic to recommend the 'freedom fighters'. Diagram 4 shows the pattern of strategic setbacks. In 1984, the Contras had the initiative and costs were higher for the FSLN than for them. From 1985 on, however, the pattern was reversed which produced a higher level of desertions and a recruitment crisis for the Contras. The Esquipulas (Guatemala) peace process has meant a further setback for the FDN as numbers of Contras taking advantage of the amnesty have increased rapidly.

Although the FDN is losing ground and the direct material costs of the war are declining, Table 1 shows the increased effectiveness of the financial war against Nicaragua and how the indirect costs of the war are skyrocketing (see Diagram 1). ${ }^{8}$

\footnotetext{
${ }^{7}$ For more details of the dialectic between the two types of defence see, 'The Contras - Chronicle of a Defeat Foretold', op.cit.
} 
Direct Losses

(millions of \$)

\begin{tabular}{|c|c|c|c|c|c|c|c|c|}
\hline \multicolumn{4}{|c|}{ Material } & \multicolumn{3}{|c|}{ Financial } & \multirow[b]{2}{*}{ Total } & \multirow{2}{*}{$\begin{array}{l}\text { Indirec } \\
\text { Effects } \\
\text { on the } \\
G D P\end{array}$} \\
\hline Year & $\begin{array}{c}\text { Destruction } \\
\text { of Capital }\end{array}$ & $\begin{array}{l}\text { Losses in } \\
\text { Production }\end{array}$ & $\begin{array}{l}\text { Sub- } \\
\text { Total }\end{array}$ & $\begin{array}{c}\text { Blocked } \\
\text { Loans }\end{array}$ & $\begin{array}{c}\text { Trade } \\
\text { Embargo }\end{array}$ & $\begin{array}{l}\text { Sub- } \\
\text { Total }\end{array}$ & & \\
\hline 1980 & 0.5 & 1.0 & 1.5 & 0.0 & 0.0 & 0.0 & 1.5 & 0.0 \\
\hline 1981 & 4.0 & 3.4 & 7.4 & 8.2 & 0.0 & 8.2 & 15.6 & 241.0 \\
\hline 1982 & 11.0 & 21.2 & 32.2 & 38.3 & 0.0 & 38.3 & 70.5 & 326.0 \\
\hline 1983 & 58.6 & 106.6 & 165.2 & 61.3 & 14.0 & 75.3 & 240.5 & 331.0 \\
\hline 1984 & 27.7 & 170.2 & 197.9 & 92.1 & 15.0 & 107.1 & 305.0 & 458.0 \\
\hline 1985 & 18.4 & 97.8 & 116.2 & 73.0 & 79.4 & 152.4 & 268.6 & 682.0 \\
\hline 1986 & 14.2 & 89.8 & 104.0 & 92.0 & 79.4 & 171.4 & 275.4 & 783.0 \\
\hline $1987^{*}$ & 10.1 & 41.5 & 51.6 & - & - & 0.0 & 51.6 & 779.0 \\
\hline Total & 144.5 & 531.5 & 676.0 & 364.9 & 187.8 & 552.7 & 1228.7 & 3600.0 \\
\hline
\end{tabular}

Source: Nicaraguan National Institute of Statistics and Census

*1987 effects on GDP estimated through end of 1987. Remaining figures for 1987 through 22 June.

\section{Diagram 1}

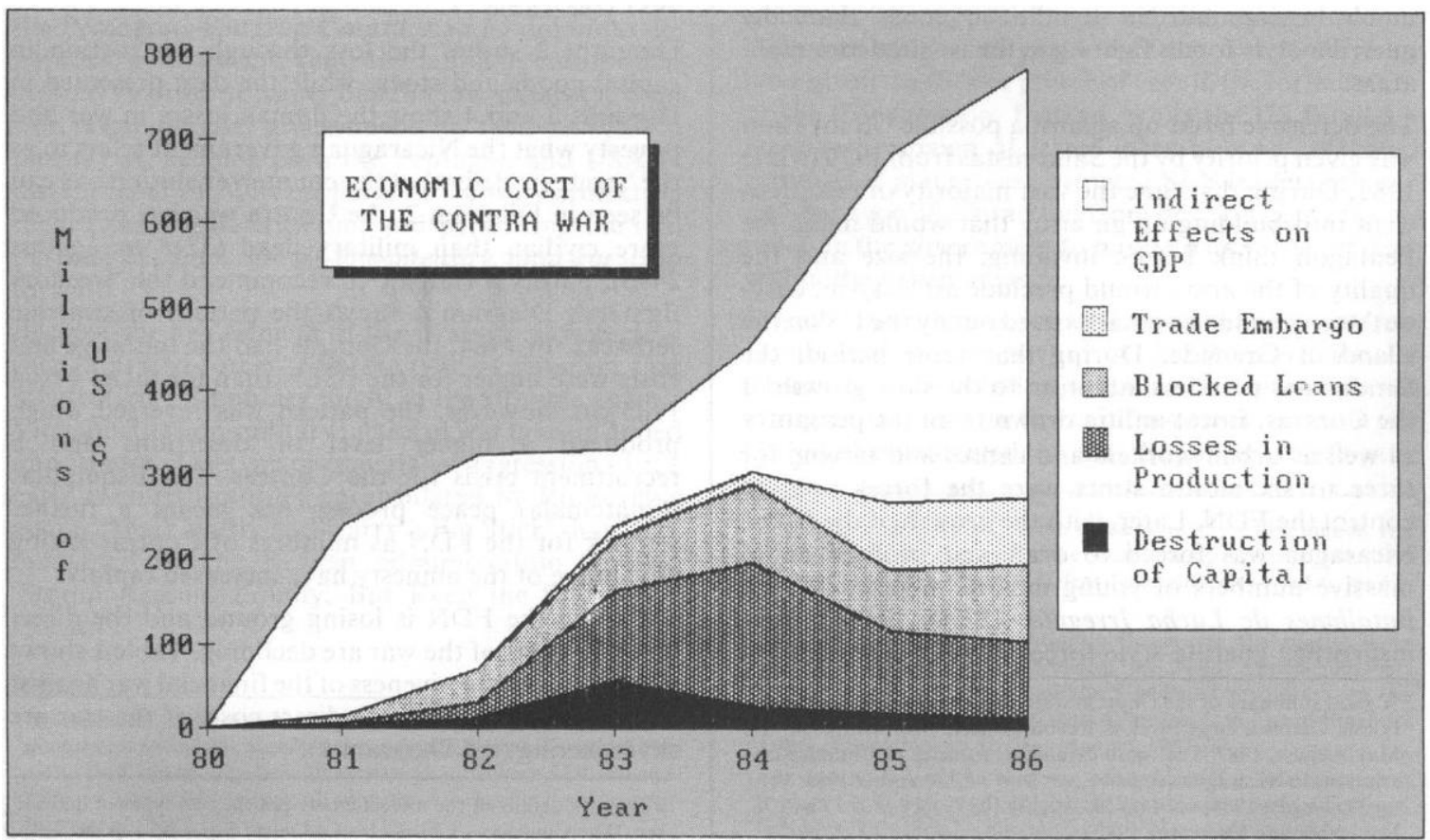




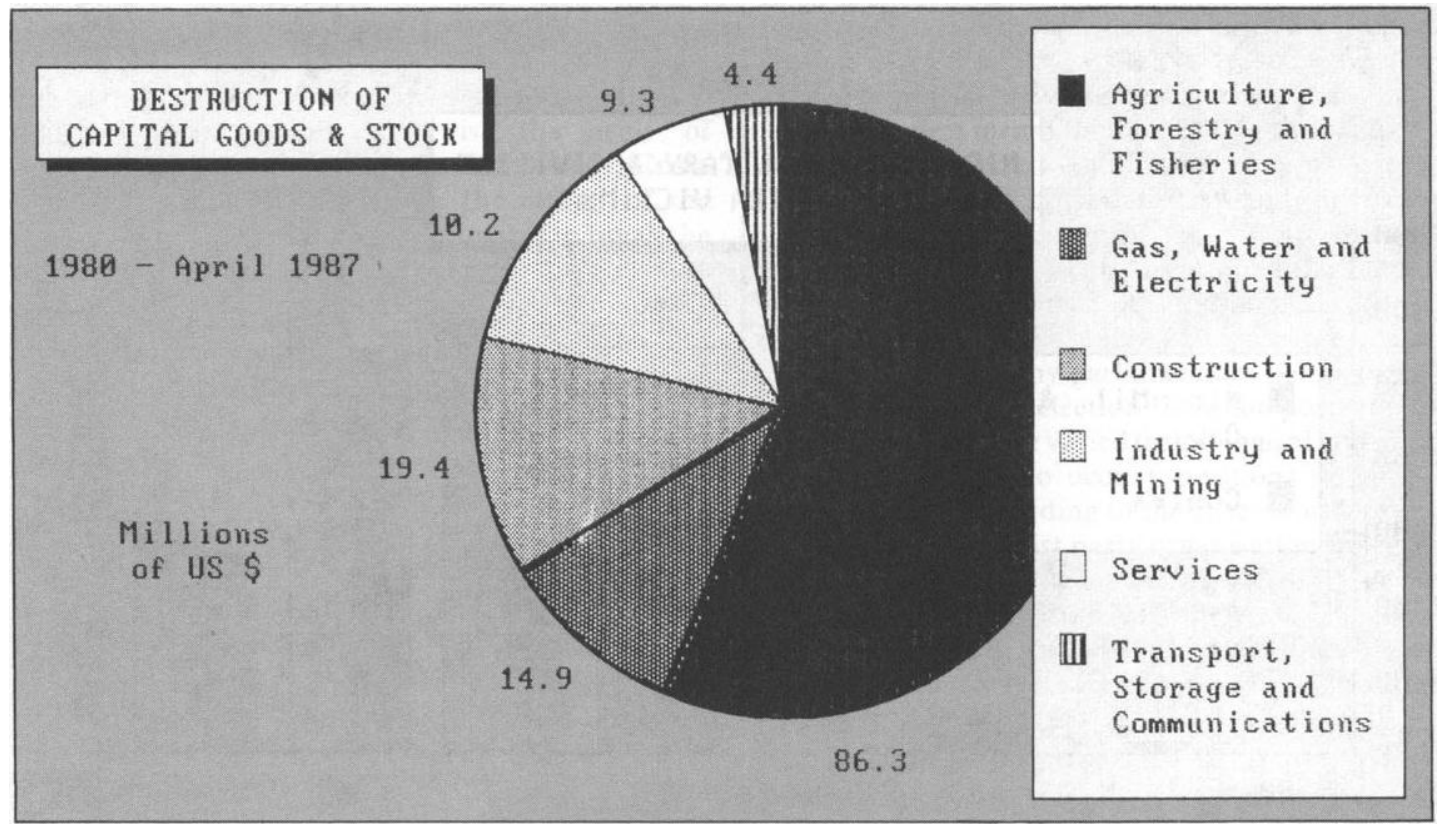

Source: Nicaraguan National Institute of Statistics and Census June 1987

\section{Digram 3}

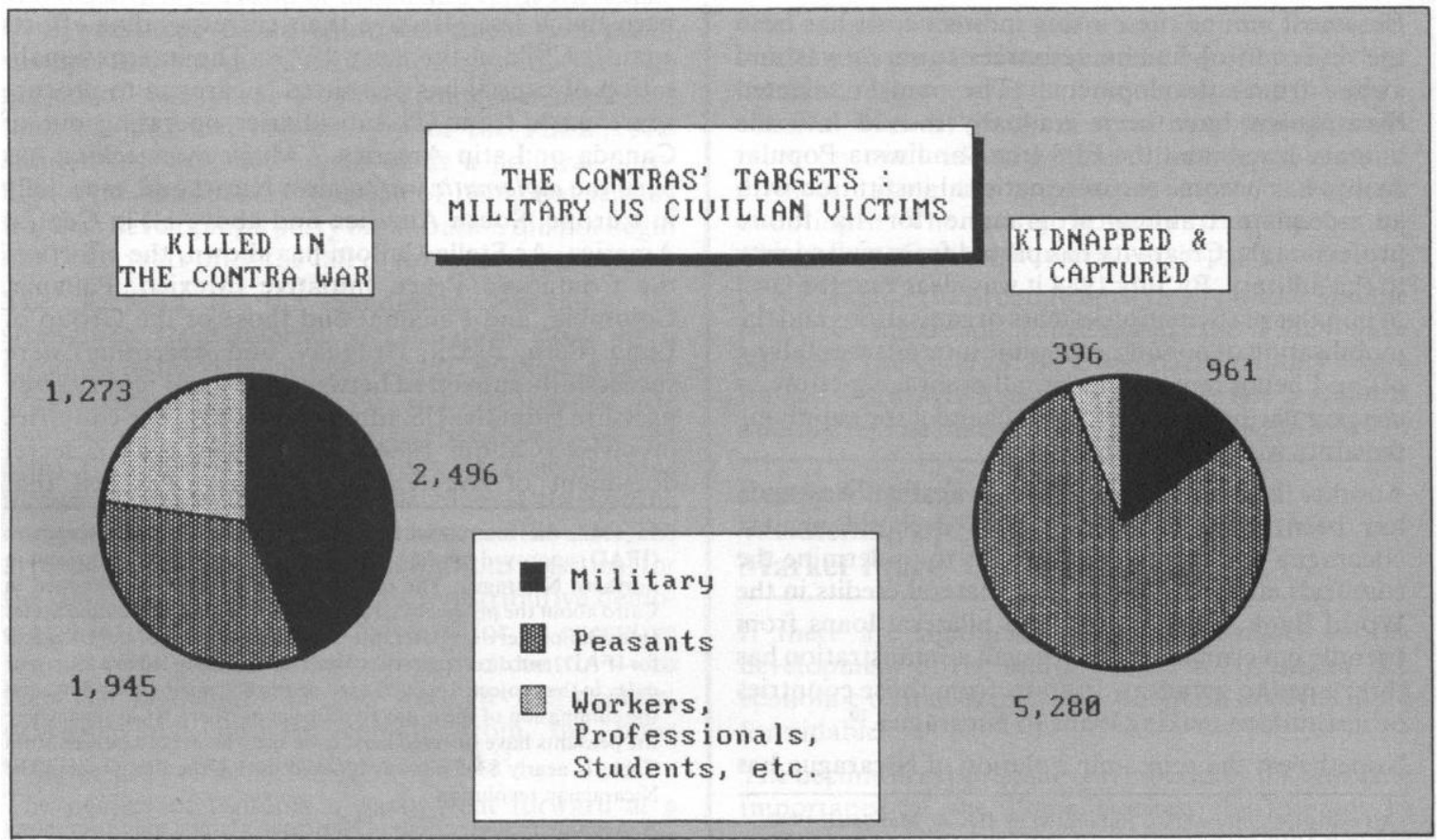

Note: 1987 Figures through 22 June

All figures are from Nicaraguan National Institute of Statistics and Census 


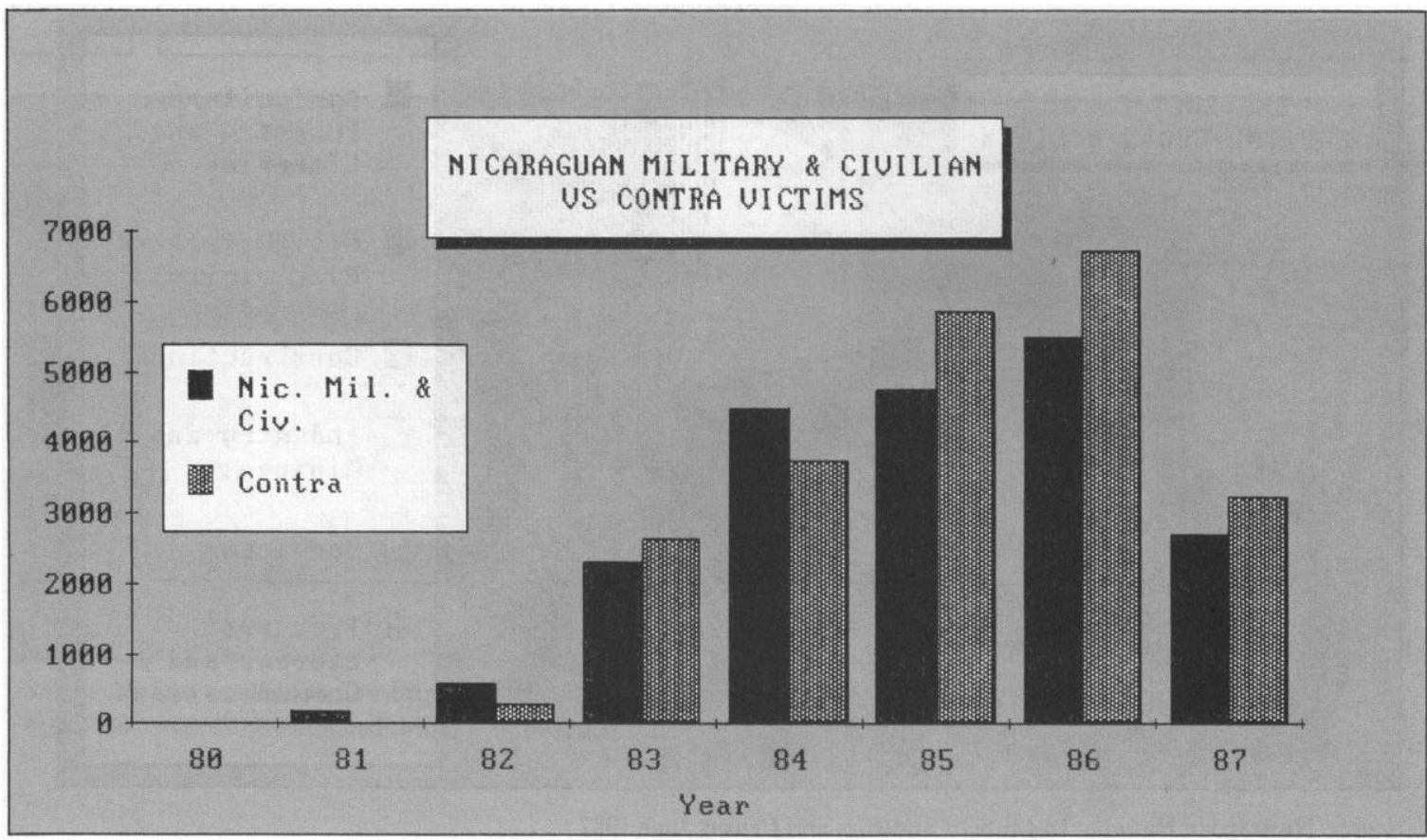

Source: Nicaraguan National Institute of Statistics and Census, April 1987

Foremost among these rising indirect costs has been the diversion of human resources towards war and away from development. The most talented Nicaraguans have been gradually moved into the military forces and the EPS (the Sandinista Popular Army) has become the only national institution with an adequate training programme for its future professionals. Creativity has passed from civil society to the military. By July 1984 it was clear that the level of popular participation in mass organisations and the mobilisation of popular economic interests was falling off and being replaced by an all-embracing effort to use popular organisations as a channel for supplying the army with new recruits. ${ }^{9}$

Another facet of the economic war against Nicaragua has been the economic boycott declared against Nicaragua and the constant efforts to undermine the country's efforts to obtain multi-lateral credits in the World Bank, the IDB etc. and bilateral loans from friendly governments. The Reagan administration has threatened to withdraw support from those countries or institutions making loans to Nicaragua. ${ }^{10}$

Nonetheless the economic isolation of Nicaragua has

${ }^{8}$ All statistical information elaborated by [HCA, Managua, 1987.

${ }^{9}$ More information regarding this phenomenon can be found in 'The

Right of the Poor to Defend Their Unique Revolution: Five Years of the Sandinista Government', Envio, vol 4 no 37, July 1984. been much less effective than corresponding efforts against Chile in the early 1970s. The internationalisation of capital has permitted Nicaragua to procure spare parts from US subsidiaries operating out of Canada or Latin America. ${ }^{11}$ Much more telling has been the diplomatic war against Nicaragua, especially in Europe, South America and above all in Central America. As Stella Calloni has shown, the efforts of the Contadora Peace Initiative (Mexico, Panama, Colombia, and Panama) and those of the Group of Lima (Peru, Brazil, Uruguay, and Argentina) were successfully subverted between 1984 and mid 1987 by pressure from the US administration on the countries involved [Calloni 1984]. In October 1984 a secret document of the National Security Council that

${ }^{10}$ In 1982, the International Fund for Agricultural Development (IFAD) approved funding for a project of peasant development in northern Nicaragua. The president of the Fund was harassed in Cairo about the project by a reporter from USIS, The United States Information Service. Later, threats of cancellation of the US quota for IFAD, and direct pressures over the evaluation led to a four-year delay in the project, a reduction of nearly $\$ 20 \mathrm{mn}$ in its funding, and the elimination of the project's scope in northern Nicaragua where the peasants have suffered most from the war. As can be seen from Table 1, nearly $\$ 365 \mathrm{mn}$ was blocked during the first years of the Nicaraguan revolution.

"A preliminary study of one of Nicaragua's largest indust ries shows that only two of the 40-odd suppliers of machinery and inputs actually acted internationally to carry out the Reagan blockage. This type of study is a rich source of analysis for academic theses. 
detailed a plan of action against Contadora was leaked. The US programme against the Latin American peace initiative was effective basically because the US had managed to isolate Nicaragua diplomatically from her Central American neighbours. Although US capacity to twist the arms of economically weak countries like El Salvador, Costa Rica and Honduras did stymie the efforts of the Contadora Peace Initiative, it was unable to break the gathering Latin American coalition against its military policy in Central America.

\section{Checks and Balances against Militarisation}

It is important to assess the type of antibodies that exist against societal militarisation in Nicaragua, for therein lies the flexibility which has permitted developmental advances, even in the midst of war.

\section{The State, the Armed Forces, Mass Organisations and the Party}

The Sandinista formula for taking power differed radically from Eastern European political models. Instead of the industrial proletariat and its political representative, the Leninist party, seizing power, in Nicaragua this was achieved by a loosely knit broad front of popular organisations (students, teachers, neighbourhoods, women, trade unions, religious groups) working with a deeply committed but weakly organised armed group of urban and rural guerrillas. In a word, the broad front movement was much stronger than the vanguard political organisation. The project of society, the utopian dream, was more real than the political organisation of the FSLN. The Sandinistas were not organised as a political party before the national insurrection of 1979 , and serious work on developing a party organisation did not begin until two years after the fall of Somoza's regime.

The decision of the Sandinista leadership to strengthen their internal organisation came as a response to the demands of the war. Without a party organisation, there was no way to resolve the innumerable tensions that developed between the army, the civilian state, and the popular organisations in every municipality of the war zone. Although the competing interests and conflict between the state, the armed forces, and the mass organisations was ideal for the development of Nicaragua's redistributive democracy, leaders quickly saw the need for an executive branch with greater coordination and control - to face the challenges of the war. In the process, developmental impulse coming from the mass organisations was seriously weakened. ${ }^{12}$

The project of building a party went forward at a snail's pace from 1982 to 1985 with the civil ministries

${ }^{12}$ For fuller analysis of the issue of popular participation see Marchetti 1986. and the armed forces refusing to give up the autonomy to which they were accustomed. After the November 1984 elections a serious attempt was made to strengthen the unity of the Nicaragua government. The attempt to unify the government under the new president elect meant in practice that the heads of the Ministries replaced the nascent party cadre as representatives of both the party and the executive branch of the government. In effect, this further weakened the minimal organisation of the Sandinista party that had occurred during the preceding years. The relation between party and state became more similar to that of any parliamentary democracy. The party that won the election filled the posts, but only with people with the varied technological and political criteria necessary to occupy positions in a modern state, and not according to the criteria under which a consolidated Leninist party organisation supervises a socialist state. As the power of the party declined, there was no third instance to moderate the economic tensions between the civilian government and the exigencies of the Defence ministry.

The weakness of the party organisation and the absence of independent bureaucratic structures to guarantee its power is the crucial phenomenon that explains why classical forms of militarisation have not occurred in besieged Nicaragua. Only when a strong party is capable of unifying the civil state under the dynamic of the military is it possible to talk about societal militarisation.

The answer to the question of whether the social model emerging in Nicaragua has been the choice of the Sandinistas or a result of their incapacity to build a classical Marxist party is something that depends more on one's ideology than on evidence, since it involves taking the Sandinistas at their word or doubting it. The fact is, however, that there is no omnipresent Eastern European-style party.

In Nicaragua, the broad front style of politics and the collective nature of leadership in the FSLN have inhibited the creation of a one-party military state. Indeed, Nicaraguan politics resemble less a stalinist military regime than they do the ruling PRI in Mexico.

\section{Penny Capitalism, Inflation, and the Weakening of State Intervention in the Market Place}

If there are significant political restraints on the development of the military state in Nicaragua, the economic obstacles to its consolidation are even more formidable.

The decline in exports, the corresponding and growing importance of the home market, the attempt to control prices and wages in both public and private sector enterprises subject to state regulation, the impossibility of controlling informal and black 
market activity, the gross incongruencies in relative prices, the high level of government subsidies, the access of the poor to scarce productive resources through political contacts, the drastic reduction in real wages in both public and private industry, have all led to the boom of penny capitalism in the informal sector of the economy. ${ }^{13}$

Frequently, scholars speak of a formal subordination of the informal sector to the dominant formal sector of the economy. In war-ridden Nicaragua, the economics of survival have reversed the existing order, and it is penny capitalism that benefits from myriad forms of unequal exchange with the public sector and private agroexport business interests.

The runaway inflation of 1987 has broken the power of the state to regulate prices and ration foodstuffs and other essentials. Rather than become more rigid and administer scarcity at bayonet point, the Nicaraguan state has simply liberalised its economic controls over more and more sectors of the economy. This is to a great extent explained by the fact that the vast informal urban sector of penny capitalists is one of the most important social bases of the FSLN. The control of the armed forces over resources has not been twinned with an increasingly powerful state, but rather with an increasingly aggressive private sector.

\section{Trends against Professionalisation within the Armed Forces}

Not only are the political and economic foundations of the Nicaraguan State less than ideal for the development of rigid militarisation, but there are several trends within the military itself which provide additional checks and balances.

The Sandinistas have armed the civilian population. More than 300,000 machine guns are under civilian control in the cities and the countryside. The key characteristic of militarism - the gulf created between the military and the civilian population - would thus be difficult to achieve in Nicaragua. Herein lies the basis for reports from travellers of the relaxed relationship between troops and civilian population, with the obvious exception of the rural war zones.

Not only are the people armed, but the struggle against the FDN in the first years of the revolution depended on non-professionalised local militia units. Currently, short stint reservists who leave their jobs for a period of a month play a crucial role in the urban defence system against a direct US invasion.

Other linkages between the military and the people occur because the economic crisis in Nicaragua does not permit the armed forces to specialise only in the

${ }^{13}$ For a study of the particular problems that Nicaragua faces in its attempts to guide the development of this burgeoning informal sector see 'Slow motion toward survival economy', Envio, vol 5 no 63 . arts of war. The army has had to take on direct production of uniforms, boots and foodstuffs in order to be able to supply itself in the war. The pressure of the war forces the army to seek rapid, efficient services in the areas of construction and supplies. This has meant that the armed forces are increasingly investing a good part of the national budget into the informal sector of the economy. The continuing boom of penny capitalism is in great part due to demand by the military for the services of these nascent family enterprises. This type of mutual dependence acts as a check against classical forms of militarism.

\section{Conclusion}

Summing up, the blast of the US war of aggression has weakened the development of the civilian state, of the Sandinista party structures and of the economic power yielded by the trade unions, block organisations, peasant organisation. Only the Armed Forces have been strengthened.

Nevertheless, the war has not undermined Nicaraguan development. Vast structural changes in the market have been carried out (agrarian reform and expansion of the small business classes) while at the same time building an institutional structure guaranteeing increased choice in the political and cultural spheres.

The increased strength of the Armed Forces has not been accompanied by their increasing presence in the political order. The civilian state lost economic resources not political power to the military. As the state became impoverished, its place has been gradually filled by an increasingly dynamic civil society vis-a-vis the state. That civil society remains anti-imperialist and Sandinista.

Even though the war has drastically eroded the income of the people, it has eroded even more the capacity of the state. To subsist the people are gradually overcoming past paternalisms and finding their own solutions in an evolving survival economy. The dignity won by the Nicaraguan people in their resistance to the war of aggression, their increasing autonomy vis-a-vis the state, their alliances with the military, and the economic reforms they have achieved represent solid bases for future development. It may take decades to reconstruct what the war has destroyed, but the bases, however, are there. The Nicaraguan people, not development, have been the victims of US aggression. When the fruits of Nicaraguan development will be harvested depends above all on an end to US military aggression in the region and on achieving a negotiated peace. As the development of the Esuquipulas Peace Process and the Sandinistas' negotiation of a cease fire with the counterrevolution are showing, the Nicaragua people are the only people in Central America whose desire for peace and development is not being 
thwarted by the vested interests of a tightly-knit oligarchy and of a national military establishment. The emerging definition of development in Nicaragua is that neither the armed forces nor the power holders in the civilian state have much to lose.

\section{References}

Barry, Deborah, Castro, Rudolfo and Vergara, Raul, 1987, Centroamerica: La Guerra de Baja Intensidad, DEI, San José
Calloni, Stella, 1984, La Guerra Encubierta contra Contadora, Centro de Capacitacion Social, Panama

Harnecker, Marta, 1987, Fidel's Political Strategy, Pathfinder Press, New York

Marchetti, Peter, 1986, 'War, popular participation, and transition to socialism; the case of Nicaragua', in R. Fagen, C. Deere, J. Coraggio (eds.), Transition and Development: Problems of Third World Socialism, Monthly Review Press, New York 